\title{
CONSTRUCTION AND VALIDATION OF A MALAY VERSION OF THE OVERACTIVE BLADDER SCREENER FOR ASSESSING URINARY TRACT SYMPTOMS IN A MALAYSIAN POPULATION
}

\author{
Muhilan AP, S Sivaprakasam, Dublin N, S Rampal, Razack AH, Thun TH, Chua CB \\ Department of Surgery, University of Malaya Medical Centre, Kuala Lumpur
}

\begin{abstract}
:
The aim of this study was to validate the translation of the Overactive Bladder (OAB) Screener $(O A B$ V8) to the Malay language. It was to assess the reliability of the screener in the context of a Malaysian population. The original screener consists of eight symptoms indicative of $O A B$ that has been proven to be highly sensitive and reliable. Translation was done with a modification of the Brislin Method using back translation and a panel of experts as a final review panel. The pilot study had two groups; a symptomatic ( $\mathrm{n}=19$ patients) and an asymptomatic group ( $\mathrm{n}=18$ patients). All patients performed the test twice at two week intervals once at the clinic and subsequently at home. Test-retest method was used for reliability and Cronbach's alpha for internal consistency. The translated questionnaire demonstrated good internal consistency in both groups of patients for all eight items individually and for the total score. Cronbach's alphas ranged from 0.972 to 0.981 for the symptomatic group and from 0.750 to 0.976 for the asymptomatic group. Testretest correlation for all items was highly significant. Intraclass correlation (ICC) was high for both the asymptomatic (ICC ranging from 0.600 to 0.953 ) and the symptomatic group (ranging from 0.944 to 0.989 ). The Malay OAB V8 showed itself to be suitable for use, reliable in distinguishing symptomatic and asymptomatic patients and a valid instrument. (JUMMEC 2009; 12(2): 74-82)
\end{abstract}

KEYWORDS: OAB, LUTS, validation, translation, questionnaire

\section{Introduction}

Overactive Bladder $(O A B)$ is a disorder affecting $10 \%$ to $20 \%$ of almost all surveyed population. It is characterized by urinary frequency, nocturia, urgency and urinary incontinence. Its primary impact is on the quality of life of those affected and their caretakers (1).

$O A B$ is very common with a prevalence of about $17 \%$ in the United States (2) and 6-35\% in Europe (3). The overall prevalence of $O A B$ symptoms in individuals aged more than 40 years was $16.6 \%$. The prevalence of $O A B$ symptoms increases with advancing age. Frequency (85\%) was the most common reported symptom, followed by urgency (54\%) and urge incontinence (36\%).

The prevalence figures for $O A B$ in South East Asia population are available from a small study done in Singapore (4), and the 1998 questionnaire based survey to study the prevalence of urinary incontinence in Asia conducted by the Asia Pacific Continence Advisory Board (APCAB) (5).
The APCAB survey involved 7875 patients attending hospital for non-urological or non-gynecological reasons $(4,5)$. Eleven countries participated in the study including China, India, Indonesia, Malaysia, Singapore, Thailand, Philippines and Taiwan. A questionnaire-based survey was performed in 5502 females (5), and 2369 men from participating countries (4). The overall prevalence from the first APCAB study was $53.1 \%$ (5) with only $21.1 \%$ seeking treatment (4). From the second male population study, the prevalence was $29.9 \%$ out of whom only $5.9 \%$ obtained treatment. Both the APCAB studies demonstrated that very few patients had sought treatment for their $\mathrm{OAB}$.

Correspondence:

Muhilan A/L A. Parameswaran

Department of Surgery

Faculty of Medicine, Universiti Malaya

50603 Kuala Lumpur, Malaysia

Email:drmuhilan@um.edu.my 
Similar figures were seen in three other separate studies from Taiwan (6) and Malaysia $(7,8)$. In Taiwan OAB had a prevalence rate of $16.9 \%$, with only $13 \%$ seeking treatment. In Malaysia, the prevalence was $19 \%$ in the female population (7) and over $6 \%$ in males over 40 years of age (8). From the $19 \%$ surveyed only $23.1 \%$ sought treatment since the majority $(76.9 \%)$ did not see $O A B$ as a problem to be treated (7).

These studies demonstrated that $O A B$ is a problem in Asia and the majority of those suffering are not under any active treatment. Many did not seek treatment either due to ignorance about the disease or the treatment options that are available.

Therefore, there is considerable scope for improvement in terms of patient awareness and understanding of $O A B$. An objective $O A B$ questionnaire/screener would be useful as its answers are in essence a patient's perception of their own disease and their evaluation of the symptoms that bother them. Currently, there are no reliable objective questionnaires for screening, evaluating symptoms or for measuring outcome (of $O A B$ ) in Malaysia-at least none that can be comprehended and used by the majority of the population. Both patients and primary care physicians would benefit from educational efforts to increase awareness of OAB. A questionnaire/screener in the local language would be a step in the right direction.

\section{Methods}

\section{Study design}

This study was conducted in two phases. The first phase was aimed at producing a cross culturally equivalent questionnaire (Figure 1). While, the second phase was focused on determining the measurement properties of the Malay questionnaire. We selected the OAB V8 (8-Item Symptom Bother Scale) based on its reliability and the reliability of its derivation from the OAB-q questionnaire $(9,10,11)$. It is the most widely used and translated $O A B$ questionnaire currently in use worldwide (12). A previous study had validated the psychometric properties of the OAB V8 (9).

In the first phase, the first step of the translation process was to obtain a basic Malay version for the foundation of the questionnaire. We used the Brislin method for translating the English questionnaire into the Malay version (13). This process is similar to the International Consultation in Incontinence Modular Questionnaire (ICIQ) protocol (14). A translator fluent in both the Malay and English language translated the English OAB V8 into Malay. Two other independent translators then back translated this Malay version into English. All the translators were bilingual and fluent in both English and Malay. They were also experienced in the art of translation; having done similar projects in the past. The first translator was provided with sufficient information concerning the purpose of the questionnaire and the underlying concept. This was to ensure the translation was valid in terms of both language and context. The next two translators were blinded to this information.

An independent committee to determine the conceptual equivalence of the Malay translation then assessed these three translations along with the original. This committee chaired by the principal investigator consisted of three doctors from the Department of Surgery, Universiti Malaya-all of whom had some background in urology and has a good command of both the Malay and English language. After detailed discussions, the committee then either accepted the items or sent it back to the translator with a list of recommendations and suggested corrections. This review process was repeated to produce a conceptually equivalent translation.

Once approved by the committee, an additional step, which was not part of the original Brislin Method, was added. This was done as we felt the additional step would improve the questionnaire from a contextual point of view. This step was the review by an Expert Committee after scrutiny by an independent translator. The Expert Committee was formed by two professors from a Social Science background and a Urology professor. They were all based in local Malaysian universities. This phase of the study was aimed at producing a cross culturally adapted Malay version with content and face validity equivalent to that of the original OAB V8.

For the second phase, we enrolled 19 symptomatic subjects and 18 subjects who did not suffer from Lower Urinary Tract Symptoms (LUTS). The subjects 
Soalan di bawah mengenai sejauhkah anda terganggu dengan gejala pundi kencing. Ada sesetengah orang akan terganggu dengan gejala pundi kencing dan tidak menyedari bahawa terdapat rawatan untuk mengubati gejala (simptom) ini. Bulatkan nombor yang dapat menjelaskan tahap kekerapan gangguan gejala( simptom) ini. Jumlahkan nombornombor ini untuk mendapat skor keseluruhan dan rekodkan skor di dalam kotak yang disediakan di bawah.

\begin{tabular}{|c|c|c|c|c|c|c|}
\hline $\begin{array}{l}\text { Berapa kerapkah anda terganggu } \\
\text { dengan gejala (simptom) di } \\
\text { bawah: }\end{array}$ & $\begin{array}{l}\text { Tidak } \\
\text { sama } \\
\text { sekali }\end{array}$ & Jarang & $\begin{array}{l}\text { Kadang- } \\
\text { kadang }\end{array}$ & Selalu & $\begin{array}{l}\text { Hampir } \\
\text { selalu }\end{array}$ & $\begin{array}{c}\text { Sepanjang } \\
\text { masa }\end{array}$ \\
\hline $\begin{array}{l}\text { 1. Kekerapan membuang air kecil/ } \\
\text { kencing pada waktu siang. }\end{array}$ & 0 & 1 & 2 & 3 & 4 & 5 \\
\hline $\begin{array}{l}\text { 2. Perasaan terdesak untuk } \\
\text { membuang kencing. }\end{array}$ & 0 & 1 & 2 & 3 & 4 & 5 \\
\hline $\begin{array}{l}\text { 3. Keinginan yang kuat secara } \\
\text { tiba-tiba untuk membuang } \\
\text { kencing dengan sedikit tanda } \\
\text { atau tanpa sebarang tanda. }\end{array}$ & 0 & 1 & 2 & 3 & 4 & 5 \\
\hline $\begin{array}{l}\text { 4. Air kencing terkeluar (beberapa } \\
\text { titik) tanpa disedari. }\end{array}$ & 0 & 1 & 2 & 3 & 4 & 5 \\
\hline $\begin{array}{l}\text { 5. Membuang air kecil pada } \\
\text { waktu malam. }\end{array}$ & 0 & 1 & 2 & 3 & 4 & 5 \\
\hline $\begin{array}{l}\text { 6. Tidur anda terganggu kerana } \\
\text { bangun untuk membuang air } \\
\text { kecil. }\end{array}$ & 0 & 1 & 2 & 3 & 4 & 5 \\
\hline $\begin{array}{l}\text { 7. Rasa hendak kencing yang tidak } \\
\text { dapat dikawal. }\end{array}$ & 0 & 1 & 2 & 3 & 4 & 5 \\
\hline $\begin{array}{l}\text { 8. Terkencing disebabkan oleh } \\
\text { rasa hendak kencing yang } \\
\text { kuat. }\end{array}$ & 0 & 1 & 2 & 3 & 4 & 5 \\
\hline
\end{tabular}

Sila tambahkan 2 poin untuk keseluruhan jumlah skor jika anda lelaki.

Lelaki/Perempuan

Nama :

Umur :

Masalah/peyakit lain :

Jumlahkan respons anda bagi soalan-soalan di atas.

Kembalikan soal selidik ini kepada doktor apabila anda menemuinya. Jika skor anda adalah 8 poin atau lebih, anda mungkin mempunyai pundi kencing yang sangat aktif. Terdapat rawatan yang efektif untuk keadaan ini. Anda mungkin ingin berbincang tentang masalah ini dengan Pegawai Perubatan.

Dr. Muhilan Parameswaran

MBBS, MRCSEd, MS (Malaya)

Lecturer, University Malaya. 


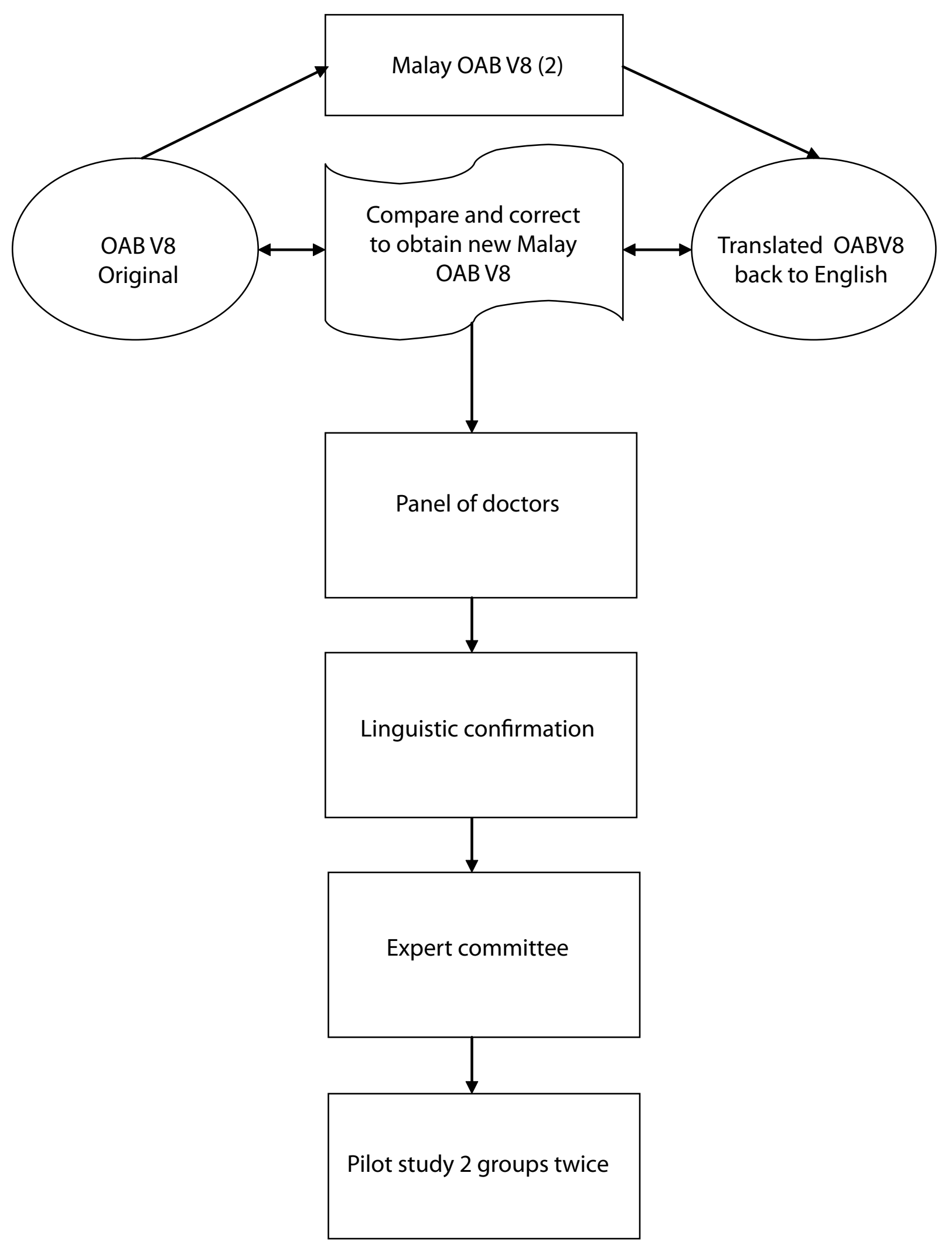

Figure 2: Overview of the cross cultural translation and adaptation of the OAB V8 from English to the Malay language. 
were selected from the University Malaya Medical Centre (UMMC) based on the presence of their symptoms. None of these subjects had ever been exposed to a OAB or LUTS questionnaire in any language. Each subject completed the questionnaire on day one and was made to repeat the questionnaire after a two week interval. The second questionnaire was to be filled at home and mailed or handed back to the investigator at a later date. As all patients were on active follow up, all questionnaires were retrieved.

\section{Statistical Analysis}

All data obtained was entered and analyzed using the Statistical Package for Social Sciences (SPSS) version 13. Data included age, sex, and ethnicity, all eight items from the first test and subsequent retest. Normally distributed continuous variables were summarized as means \pm standard deviation (SD). The independent T-test was used to test differences between two independent means. Whereas, differences between two dependent means were tested using the paired T-test. When there were more than two independent means, the one-way analysis of variance (ANOVA) was used.

Their non-parametric equivalent tests were used when the distributions were not normal. Categorical variables are summarized as proportions and any differences were tested using the Fishers exact test. All hypothesis testing considered a two sided $p<0.05$ to be statistically significant.

The psychometric properties of the Malay version of $O A B V 8$ were calculated using the following:

1. Interclass correlation - Interclass correlation was used to assess the variation in total score among the different races. Wilcoxon/Mann-Whitney $U$ test was further used to analyze the significance of the mean age difference between the groups.

2. Test-retest reliability - This was assessed using the intraclass correlation (ICC) which was arrived at by using Analysis of Variance (ANOVA). All eight points of the questionnaire were subjected to this testing with both groups being analyzed separately. Paired T-test was used to further assess the test-retest reliability
3. Scale Reliability - Cronbach's alpha coefficient was used to measure the internal consistency of the domains and the total score.

4. Discriminant validity - Independent T-test was to test for differences between the two groups as a measure of discriminant validity using Levene's Test for Equality of Variances.

5. Diagnostic performance - This was evaluated using the area under the Receiver Operating Characteristic (ROC) curve.

\section{Results}

\section{Study Population}

This study enrolled a total of 37 subjects. Of the 19 symptomatic subjects, 13 (68.4\%) were females whereas $11(61.1 \%)$ of the 18 asymptomatic subjects were females $(p=0.74)$. The distribution of age among the subjects violated parametric assumptions, thus medians and the Mann Whitney $U$ test was used. The median age of the symptomatic group did not significantly differ from the asymptomatic group $(p=0.26)$. All the three major races in MalaysiaMalay, Chinese and Indian-were represented in both groups. In the symptomatic group Malays (57.9\%) were the majority followed by the Indians (26.3\%) and Chinese (15.8\%). This was not statistically different from the asymptomatic group that was made up of $66.7 \%$ Malays, $22.2 \%$ Indians and $11.1 \%$ Chinese $(p=1.00)$.

\section{Interclass correlation}

Interclass correlation was used to assess for variation in the scores between the different races. The results showed no significant difference between the various ethnic groups in terms of their total score $(p=0.737)$. Hence, the conclusion was that the members of the various races answered with the same degree of reliability.

\section{Discriminant validity}

Furthermore, using the independent T-test we tested for the questionnaire's discriminant validity. The null hypothesis was that there were no difference in the scores between the symptomatic group and asymptomatic group. The mean score of $27.20 \pm 2.19$ 
Table 1: Validity and reliability for symptomatic individuals

\begin{tabular}{|c|c|c|c|c|c|c|}
\hline & \multirow{2}{*}{ ICC } & \multirow{2}{*}{$\begin{array}{c}\text { Cronbach's } \\
\text { Alpha }\end{array}$} & \multirow{2}{*}{$\begin{array}{l}\text { Paired Mean } \\
\text { Difference }\end{array}$} & \multicolumn{2}{|c|}{ 95\% Confidence Interval } & \multirow{2}{*}{$p$ value } \\
\hline & & & & Lower & Upper & \\
\hline Q1 & 0.963 & 0.981 & 0.16 & -0.02 & 0.34 & 0,083 \\
\hline Q2 & 0.981 & 0.990 & 0.10 & -0.05 & 0.26 & 0,331 \\
\hline Q3 & 0.963 & 0.979 & 0.10 & -0.12 & 0.33 & 0,163 \\
\hline Q4 & 0.974 & 0.986 & 0.10 & -0.12 & 0.33 & 0,331 \\
\hline Q5 & 0.944 & 0.971 & 0.10 & -0.05 & 0.26 & 0,163 \\
\hline Q6 & 0.952 & 0.975 & 0.05 & -0.14 & 0.25 & 0,578 \\
\hline Q7 & 0.951 & 0.972 & 0.32 & 0.04 & 0.60 & 0,030 \\
\hline Q8 & 0.971 & 0.985 & -0.05 & -0.25 & 0.14 & 0,578 \\
\hline Total & 0.989 & 0.994 & 0.90 & 0.22 & 1.57 & 0,013 \\
\hline
\end{tabular}

Table 2: Validity and reliability for asymptomatic individuals

\begin{tabular}{|c|c|c|c|c|c|c|}
\hline & \multirow{2}{*}{ ICC } & \multirow{2}{*}{$\begin{array}{c}\text { Cronbach's } \\
\text { Alpha }\end{array}$} & \multirow{2}{*}{$\begin{array}{l}\text { Paired Mean } \\
\text { Difference }\end{array}$} & \multicolumn{2}{|c|}{ 95\% Confidence Interval } & \multirow{2}{*}{$p$ value } \\
\hline & & & & Lower & Upper & \\
\hline Q1 & 0.928 & 0.955 & 0.06 & -0.06 & 0.17 & 0.331 \\
\hline Q2 & 0.804 & 0.892 & 0.00 & -0.17 & 0.17 & 1.000 \\
\hline Q3 & 0.600 & 0.750 & 0.00 & -0.17 & 0.17 & 1.000 \\
\hline Q4 & 0.721 & 0.830 & 0.11 & -0.05 & 0.27 & 0.163 \\
\hline Q5 & 0.893 & 0.915 & 0.06 & -0.15 & 0.26 & 0.579 \\
\hline Q6 & 0.837 & 0.908 & 0.06 & -0.06 & 0.17 & 0.331 \\
\hline Q7 & 0.825 & 0.895 & 0.00 & -0.17 & 0.17 & 1.000 \\
\hline Q8 & 0.931 & 0.948 & 0.06 & -0.06 & 0.17 & 0.331 \\
\hline Total & 0.953 & 0.976 & 0.33 & 0.04 & 0.63 & 0.029 \\
\hline
\end{tabular}

for the symptomatic group was significantly higher as compared to the asymptomatic group (mean=10.61 \pm 0.46 ) with a $p<0.0001$. This indicates the ability of the questionnaire to discriminate between symptomatic and asymptomatic patients.

\section{Test-retest reliability}

Reliability was performed separately for the two groups of subjects. Table 1 shows the scale reliability for the symptomatic group. The Cronbach's alphas for the symptomatic group ranged from 0.972 to 0.981 for the symptom bother score. This was associated with an Intraclass correlation coefficient (ICC) ranging from 0.944 to 0.989 . This demonstrates high internal consistency. There was a significant difference in the paired scores of item 7 (mean difference of $0.32,95 \% \mathrm{Cl} 0.04,0.60$ ) and in the total scores (mean difference of $0.89,95 \% \mathrm{Cl} 0.22$, 1.57). Though statistically significant, the differences were not clinically significant, and such variations are unlikely to affect the outcome of the screener. 


\section{Scale Reliability}

Table 2 shows in the group of asymptomatic patients, the questionnaire showed more variability. The asymptomatic group's score while not as high as the symptomatic group is still acceptable with a Cronbach's alphas from 0.750 to 0.976 for the symptom bother score. This was associated with an ICC ranging from 0.600 to 0.953 . This indicates that this group also has a high level of internal consistency and reliability. The ICC was lowest for items 3 and 4. For items 3 , the correlation was 0.600 with a non-significant mean paired difference of $0.00(95 \% \mathrm{Cl}-0.3171,0.171)$. For item 4 the correlation was 0.721 with a non-significant mean paired difference of $0.11(95 \% \mathrm{Cl}-0.50,0.272)$. Interestingly, the total scores of the screener showed very good reliability with a score of 0.953 and had a significant mean difference between the test and retest of $0.333(95 \% \mathrm{Cl} 0.038,0.629)$. However, it is unlikely that this small difference will affect the interpretation of this screener.

\section{ROC Curve}

As expected the diagnostic performance of the questionnaire in this study comparing the symptomatic and asymptomatic subjects was very good. The area under the Receiver Operating Curve (ROC) was very high at 0.988 . For screening, an optimum screening score of $>12$ gave a sensitivity of $94.7 \%$ with a specificity of $83.4 \%$.

\section{Discussion}

The Brisilin method of translation is currently the most widely used method of translation. Most of the other language translations of the OAB V8 also utilized this method. Due to the format used, the process of translation, back translation and so on, there are numerous check and balances to identify and correct mistakes either from a linguistic or contextual point of view. Additionally, it is the current standards to which urology questionnaire translations are performed as set out by the ICIQ protocol. The limitation of this method is that it is manpower intensive as it requires two independent teams of translators and an expert committee who all need to work together.

In general, it should be easy to translate a sentence from English to Malay as the written language uses the same alphabet and a number of Malay words are derived from English. The problem arises in that words that are directly derived may not be understood. Also contrary to popular belief Malay is not a homogenous language and there is variation from region to region. Further problems arose from the fact many disease symptoms do not translate well into the Malay language and require contextual rather than linguistic translation to make it accurate for example Urgency, urge incontinence or even incontinence. The concept of incontinence and urgency do not exist per se and need to be explained out. This can be a major problem in a questionnaire requiring self administration by the subject/patient.

For certain words it was difficult to translate using terms that were not considered rude. Hence in some parts two words with the same meaning were used to explain this e.g. "membuang air kecil" and "kencing" for micturation. In trying to overcome this problem it was decided to emphasize the meaning or the concept behind the question, rather than literary accuracy. In view of the above problems we decided to invite Bi-lingual social scientist and urologist to form an expert committee to evaluate the context of the question and make it more understandable and acceptable to Malaysians regardless of their background. This step is a deviation from current ICIQ protocols but a necessary one given the circumstances.

In the second phase of the study on the validation of data from the Malay OAB V8, it had performed as reliably as the original. It demonstrated great consistency in being to differentiate symptomatic and asymptomatic patients hence being able to act as a screener for OAB patients locally. The mean score of $27.20 \pm 2.19$ for the symptomatic group was significantly higher as compared to the asymptomatic group (mean $=10.61 \pm$ $0.46)$ with a $p<0.0001$.

Any bias from the presence of medical staff was eliminated by the fact that the questionnaire was self administered at home for a second time two weeks later and the subjects still answered with a great deal of consistency. Mean difference between the test and retest of $0.333(95 \% \mathrm{Cl} 0.038-0.629)$.

The questionnaire demonstrated good internal consistency reliability, test-retest reliability, 
discriminant validity. However, the high diagnostic performance (high specificity and sensitivity) (ROC is high at 0.988 ) should be viewed with caution. A screener is expected to be highly sensitive but not very specific, criteria met by the $O A B$ V8 (sensitivity of $94.7 \%$ with a specificity of $83.4 \%$ ). This is because the two groups were selected based on the presence of their symptoms. The symptomatic groups had gross $O A B$ and the asymptomatic patients were healthy individuals. The wide variation in the symptoms may have influenced the study.

The data obtained is remarkable considering the difficulties encountered with the language and the unfamiliarity of many of the subjects with the use of written questionnaires as a form of data collection. However there was no control group for comparison i.e. those using the English $O A B$ V8 for comparison in regards to use of a questionnaire.

A larger cross-sectional study should resolve any doubts about the sensitivity and specificity in relation to the ROC curve and comparison against subjects answering using the $O A B$ V8 English should answer any questions on administration of a questionnaire.

The limitations encountered were in the selection of patients as a truly randomized population survey would not accurately reflect the population characteristics e.g. Malaysian population is predominantly Malay (65\%) however the urban population served by the hospital (UMMC) has a larger percentage of Indian and Chinese patients.

\section{Conclusion}

The Malay OAB V8 showed itself to be suitable for use in the community. It was reliable in distinguishing symptomatic and asymptomatic patients and is a valid instrument for studies to be conducted in Malaysia.

Declaration: This study was done with a research grant from Pfizer Inc.

\section{References}

1. Perrault L, Brown R, Benedict A, Kessabi S, Omar M. Impact of symptom severity on the direct costs of OAB in the US. BJUI 2004; 94 (Suppl 2): 74-75.
2. Stewart WF, Van Rooyen JB, Cundiff GW, Abrams P, Herzog AR, Corey $R$, et al. Prevalence and burden of overactive bladder in the United States. World J Urol 2003; 20(6): 327-336.

3. Milsom I, Abrams P, Cardozo L, Roberts RG, Thüroff $J$, Wein AJ. How widespread are the symptoms of an overactive bladder and how are they managed? A population-based prevalence study. BJUI 2001; 87(9): 760-766.

4. Moorthy P, Lapitan MC, Quek PL, Lim PA. Prevalence of overactive bladder in Asian men: An epidemiological survey. BJUI 2004; 93(4): 528531.

5. Lapitan MC, Chye PL; Asia-Pacific Continence Advisory Board. The epidemiology of overactive bladder among females in Asia: A questionnaire survey. Int Urogynecol J Pelvic Floor Dysfunct 2001; 12(4): 226-231.

6. Yu HJ, Liu CY, Lee KL, Lee WC, Chen TH. Overactive Bladder Syndrome among community dwelling adults in Taiwan: Prevalence, correlates, perception, and treatment seeking. Urol Int 2006; 77(4): 327333.

7. Low BY, Liong $M L$, Yuen $\mathrm{KH}$, Chong $\mathrm{WL}$, Chee $\mathrm{C}$, Leong WS, et al.Study of prevalence, treatment seeking behavior and risk factors of women with lower urinary tract symptoms in Northern Malaysia. Urology 2006; 68(4): 751-758.

8. Mariappan P, Chong WL. Prevalence and correlations of lower urinary tract symptoms, erectile dysfunction and incontinence in men from a multiethnic Asian population: results of a regional population-based survey and comparison with industrialized nations. BJUI 2006; 98(6): 12641268.

9. Screener in a Primary Care Patient Population In The US. Presented at 34th Joint Meeting of the International Continence Society and The international Urogynecological Association. Neurourol Urodynamics 2004; 23(5/6): 95.

10. Coyne K, Revicki D, Hunt T, Corey R, Stewart W, Bentkover J, et al. Psychometric validation of an overactive bladder symptom and health-related quality of life questionnaire: the OAB-q. Qual Life Res 2002; 11(6): 563-574. 
11. Abrams P, Avery K, Zyeynski T, Kopp Z, Coyne K. Measuring patient outcomes in $O A B$ : the $O A B-Q$, OAB-O SF, OAB screener and ICIQ-OAB. Available from http: //www.icsoffice.org/publications/2004/ pdf/0003.pdf.

12. Matza LS, Zyczynski TM, Bavendam T. A rReview of quality-of-life questionnaires for urinary incontinence and overactive bladder: which ones to use and why? Curr Urol Rep 2004; 5(5): 336-342.

13. Brisilin, RW. (Ed.). (1976). Translation, applications and research. New York: Gardner Press. Review article of book by R. W. Brisilin - Roger Spielmann. Contemporary Sociology, Vol. 6, No. 6 (Nov., 1977), pp. 664-665 doi: 10.2307/2066325.

14. International Consultation in Incontinence Modular questionnaire (ICIQ) protocol. Available from http: //www.iciq.net/links.html.
15. Shaw C, Matthews RJ, Perry SI, Assassa RP, Williams $\mathrm{K}$, Mcgrother $\mathrm{C}$, et al. The Leicestershire MRC Incontinence Study Team. Validity and reliability of an interviewer-administered questionnaire to measure the severity of lower urinary tract symptoms of storage abnormality: the Leicester Urinary Symptom Questionnaire. BJUI 2002; 90(3): 205-215.

16. Coyne KS, Matza LS. Validation of the perception of bladder condition measure in overactive bladder. Poster presented at: the 7th Annual International Meeting of the International Society for Pharmacoeconomics and Outcomes Research (published abstract); May 19-22, 2002; Arlington, VA. 


\title{
ENSURING PATIENT SAFETY IN THE NEW OPERATING THEATRE OF UMMC TRAUMA CENTRE; AN ANAESTHESIOLOGIST NOVICE EXPERIENCE
}

\author{
Mamat $M^{1}$, Chan $L^{2}$ \\ ${ }^{1}$ Faculty of Medicine, Universiti Teknologi Mara (UiTM), Malaysia \\ ${ }^{2}$ Department of Anaesthesiology, Faculty of Medicine, Universiti Malaya, Kuala Lumpur
}

\begin{abstract}
Patient safety is a serious global healthcare issue. Harm can be caused by a range of errors or adverse events. Therefore, it is vital that the commissioning of a new operating theatre should comply to the highest standard before it is allowed to function. This paper accounts our experience in the commissioning of the University Malaya Medical Centre (UMMC) trauma centre operating theatre (OT) complex in July 2008. We highlighted the problems we faced in adhering to the international standard guidelines. Unanticipated events were handled professionally and solved. With this experience, we hope that the identified problems would provide suggestions for commissioning an operating theatre in the local setting in the future. (JUMMEC 2009; 12 (2): 83-91)
\end{abstract}

KEYWORDS: patient safety, operating theatre commission.

\section{Introduction}

Under the 7th Malaysian Plan, a modern trauma and emergency centre was constructed at the forefront of the University Malaya Medical Centre (UMMC). It became operational in 2003. However, the operating theatre (OT) which was designed to compliment urgent emergency surgeries never took off for various reasons. It was not until recently, after an understanding between the UMMC OT committee members that the long awaited functioning of the trauma centre OT came into existence. The need is timely with the increasing emergency surgeries done in the main OT complex.

The Anaesthesiology Department, UMMC was given the responsibility to check and certify that the OT was safe for use. The safety issues included all aspects of patient's care and the needs and services of healthcare staff and supporting staff.

\section{Objective}

Patient safety is a serious global healthcare issue. Estimates showed that in developed countries, 10\% was harmed while receiving hospital care (1). The harm can be caused by a range of errors or adverse events. Therefore it is vital that the OT inspection should comply to the highest standard and "zero-defect" from avoidable causes.
We hope that we can identify in the local setting common problems associated with commissioning an OT in UMMC.

\section{Methodology}

The Anaesthesiology Department team members comprised of a clinical consultant and two medical officers (one senior medical officer and a Master of Anaesthesiology trainee). We were supported by the nursing team which comprised the matron, two sisters, and five staff nurses.

A checklist, which complied to the World Health Organisation (WHO) standards, the recommended minimum OT facilities guidelines set by the Australian and New Zealand College of Anaesthestists (ANZCA) and the standards set by the Ministry of Health of Malaysia (2-6), was prepared by the consultant anaesthesiologist. The checklist was divided into two parts: the physical aspects and the patient related aspects. The inspection

\footnotetext{
Correspondance :

Mafeitzeral Mamat

Department of Anaesthesiology,

Faculty of Medicine, Universiti Malaya,

50603, Kuala Lumpur, Malaysia

Email: mafeitz@gmail.com
} 
and ratification was done on the 7th and 8th of July, 2008. The OT started its first case on the 9th of July, 2008.

In this exercise, if the OT was found to be unsatisfactory, surgical operations were postponed to a later date after the major problems were rectified. This consensus was in tandem with upholding patients' safety.

\section{Results}

Using the prepared checklist, we double checked with the UMMC Engineering team with the cooperation of the Microbiology Department that they had completed the steps below (done between weeks 1 June and 30 June, 2008:

1. The OT interior was checked for obvious defects

2. The air distribution within the theatre and between rooms in the theatre suite was satisfactory. The air handling unit supplying the theatre was properly constructed, the theatre was properly constructed, finished and functioning

3. The air change rates in OT and preparation room wa satisfactory

4. Airborne microbial contamination in an empty OT was satisfactory (ICT)

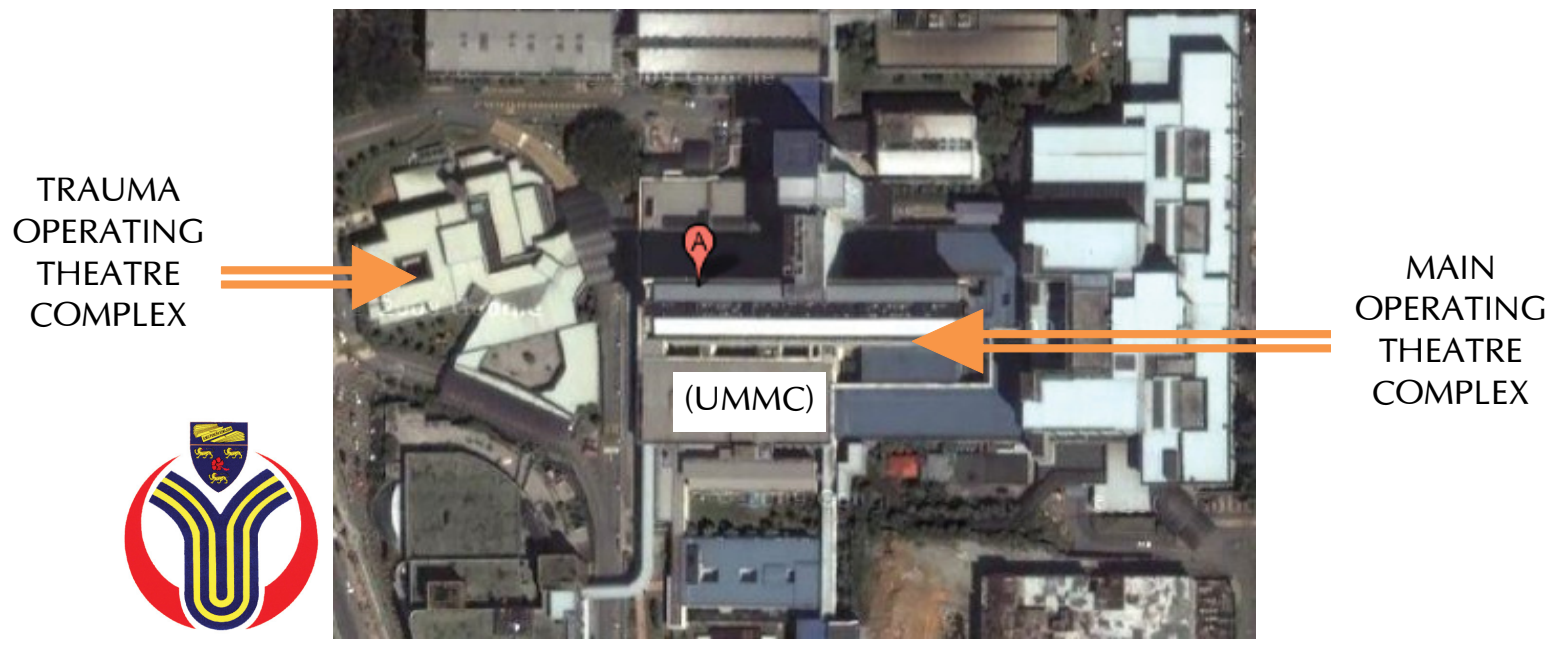

Figure 1: The Universiti Malaya Medical Centre (UMMC) complex

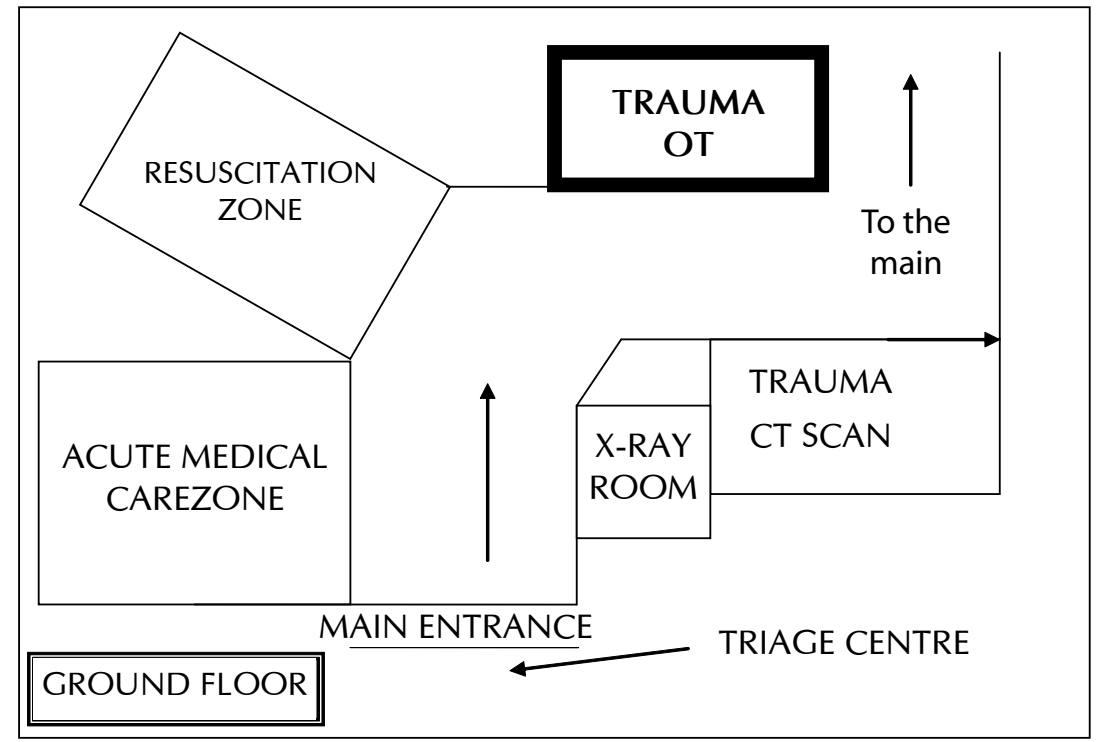

FRONT OF TRAUMA CENTRE

Figure 2: Trauma Operating Theatre (OT) in the Trauma and Emergency Centre 
The commissioning checklist was divided into two parts: the physical aspects and the patient related aspects. There were few sub sections that went under vigorous scrutiny. Being abandoned for several years, there were lots of technical glitches which needed to be rectified. Most of the problems with equipment arose from its non-usage for several years.

\section{Physical Aspects}

\begin{tabular}{|c|c|c|c|}
\hline \multirow{3}{*}{ 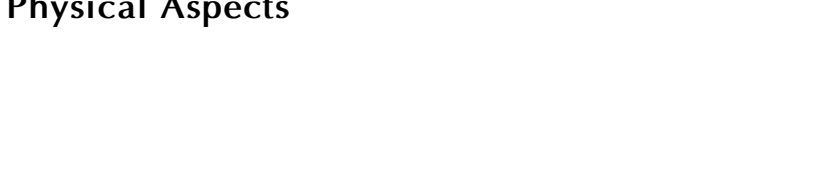 } & \multirow{2}{*}{\multicolumn{2}{|c|}{7 July 2009}} & \multirow{3}{*}{$\begin{array}{l}8 \text { July } 2009 \\
\begin{array}{l}\text { Satisfactory And } \\
\text { Rectified }\end{array}\end{array}$} \\
\hline & & & \\
\hline & $\begin{array}{l}\text { Satisfactory } \\
\mathrm{Y} / \mathrm{N}\end{array}$ & $\begin{array}{l}\text { Immediate Attention } \\
\text { and Action }\end{array}$ & \\
\hline Reception & $\mathrm{N}$ & Phone faulty & $\sqrt{ }$ \\
\hline Changing Room & $\mathrm{Y}$ & & $\sqrt{ }$ \\
\hline Transfer Bay & Y & & $\sqrt{ }$ \\
\hline $\begin{array}{l}\text { OT } 1 \text { safe practice: } \\
\text { - Warning devices in medical gas pipeline systems, } \\
\text { to alarm when bulk gas supplies are low. }\end{array}$ & $\mathrm{N}$ & Engineering & $\sqrt{ }$ \\
\hline $\begin{array}{l}\text { - Electrical supply and equipment designed to } \\
\text { eliminate risk of microshock. }\end{array}$ & $\mathrm{Y}$ & & $\sqrt{ }$ \\
\hline - Emergency lighting and power supply. & $\mathrm{N}$ & Engineering & $\sqrt{ }$ \\
\hline $\begin{array}{l}\text { - Means of controlling the temperature within } \\
\text { the range of } 20^{\circ} \mathrm{C} \text { to } 28^{\circ} \mathrm{C} .\end{array}$ & $\mathrm{N}$ & Engineering & $\sqrt{ }$ \\
\hline - A wall clock with a sweep second hand. & $\mathrm{N}$ & Not working & $\sqrt{ }$ \\
\hline $\begin{array}{l}\text { - Provision for scavenging waste anaesthetic } \\
\text { gases and vapours. }\end{array}$ & $\mathrm{N}$ & Engineering & $\sqrt{ }$ \\
\hline $\begin{array}{l}\text { - Means of communicating with persons outside } \\
\text { theatre. }\end{array}$ & $\mathrm{Y}$ & & $\sqrt{ }$ \\
\hline $\begin{array}{l}\text { - Separate refrigerators: correct storage of blood } \\
\text { and biological products. }\end{array}$ & $\mathrm{Y}$ & & $\sqrt{ }$ \\
\hline $\begin{array}{l}\text { Standard equipment } \\
-12 \text {-lead electrocardiograph. }\end{array}$ & $\mathrm{Y}$ & & $\sqrt{ }$ \\
\hline - A defibrillator. & $\mathrm{Y}$ & & $\sqrt{ }$ \\
\hline $\begin{array}{l}\text { - A manual, self-inflating resuscitator bag capable } \\
\text { of delivering up to } 100 \% \text { oxygen (e.g. Laerdal, } \\
\text { Ambu bags). }\end{array}$ & $\mathrm{Y}$ & & $\sqrt{ }$ \\
\hline - Central venous pressure sets. & $\mathrm{N}$ & OT Staff & $\sqrt{ }$ \\
\hline $\begin{array}{l}\text { - Means of infusing intravenous fluids under } \\
\text { pressure. }\end{array}$ & $\mathrm{Y}$ & & $\sqrt{ }$ \\
\hline - Blood warming apparatus. & $\mathrm{Y}$ & & $\sqrt{ }$ \\
\hline - Means of insulating the patient against heat loss. & $\mathrm{Y}$ & & $\sqrt{ }$ \\
\hline $\begin{array}{l}\text { - Means of providing or conserving airway } \\
\text { humidification. }\end{array}$ & $\mathrm{Y}$ & & $\sqrt{ }$ \\
\hline - Intercostal catheter drainage set. & $\mathrm{N}$ & OT Staff & $\sqrt{ }$ \\
\hline $\begin{array}{l}\text { - Trays suitable for spinal, epidural and regional } \\
\text { nerve blocks. }\end{array}$ & $\mathrm{Y}$ & & $\sqrt{ }$ \\
\hline - Equipment for difficult intubations. & $\mathrm{Y}$ & & $\sqrt{ }$ \\
\hline - Patient trolleys capable of rapid tilting. & $\mathrm{Y}$ & & $\sqrt{ }$ \\
\hline $\begin{array}{l}\text { - A refrigerator for the storage of drugs required } \\
\text { to be stored in the cold. }\end{array}$ & $\mathrm{N}$ & & $\sqrt{ }$ \\
\hline
\end{tabular}




\section{Physical Aspects (continued)}

\begin{tabular}{|c|c|c|c|}
\hline & \multicolumn{2}{|c|}{7 July 2009} & \multirow{2}{*}{$\frac{8 \text { July } 2009}{\begin{array}{c}\text { Satisfactory And } \\
\text { Rectified }\end{array}}$} \\
\hline & $\begin{array}{l}\text { Satisfactory } \\
\mathrm{Y} / \mathrm{N}\end{array}$ & $\begin{array}{l}\text { Immediate Atten- } \\
\text { tion and Action }\end{array}$ & \\
\hline \multirow{2}{*}{\multicolumn{4}{|c|}{$\begin{array}{l}\text { Anaesthesia equipment } \\
\text { 1. Each anaesthetic machine must have the } \\
\text { following safety features: }\end{array}$}} \\
\hline & & & \\
\hline a) An indexed gas connection system. & $\mathrm{Y}$ & & $\sqrt{ }$ \\
\hline $\begin{array}{l}\text { b) A reserve cylinder supply of oxygen and, where } \\
\text { appropriate, nitrous oxide. }\end{array}$ & $\mathrm{N}$ & OT Staff & $\sqrt{ }$ \\
\hline c) An oxygen supply pressure warning device. & $\mathrm{Y}$ & & $\sqrt{ }$ \\
\hline $\begin{array}{l}\text { d) An oxygen analyser/monitor with a low oxygen } \\
\text { alarm. }\end{array}$ & $\mathrm{Y}$ & & $\sqrt{ }$ \\
\hline e) Each anaesthetic machine should include: & & & \\
\hline $\begin{array}{l}\text { (i) Calibrated vaporisers for accurate delivery of } \\
\text { inhalational anaesthetics. }\end{array}$ & $\mathrm{Y}$ & & $\sqrt{ }$ \\
\hline (ii) A range of suitable breathing systems. & $\mathrm{Y}$ & & $\sqrt{ }$ \\
\hline $\begin{array}{l}\text { (iii) Breathing systems suitable for paediatric } \\
\text { anaesthesia }\end{array}$ & $\mathrm{Y}$ & & $\sqrt{ }$ \\
\hline $\begin{array}{l}\text { 2. An automatic mechanical ventilator, with a } \\
\text { disconnection alarm, must be available for } \\
\text { each anaesthetised patient. }\end{array}$ & Y & & $\sqrt{ }$ \\
\hline $\begin{array}{l}\text { 3. Suction apparatus } \\
\text { (complying with BS4199, AS2120 or } \\
\text { equivalent), including hand pieces (e.g. } \\
\text { Yankauer) and a range of endotracheal } \\
\text { catheters, for the exclusive use of the } \\
\text { anaesthesiologist. }\end{array}$ & $\mathrm{Y}$ & & $\sqrt{ }$ \\
\hline 4. Alternative suction system & $\mathrm{Y}$ & & $\sqrt{ }$ \\
\hline 5. Standard intubation equipment & $\mathrm{Y}$ & & $\sqrt{ }$ \\
\hline Recovery Area & $\mathrm{Y}$ & & $\sqrt{ }$ \\
\hline
\end{tabular}

\section{Patient Related Aspects}

\begin{tabular}{|c|c|c|c|}
\hline & \multicolumn{2}{|c|}{7 July 2009} & \multirow{2}{*}{$\begin{array}{c}8 \text { July } 2009 \\
\begin{array}{c}\text { Satisfactory And } \\
\text { Rectified }\end{array}\end{array}$} \\
\hline & $\begin{array}{c}\text { Satisfactory } \\
Y / N\end{array}$ & $\begin{array}{l}\text { Immediate Atten- } \\
\text { tion and Action }\end{array}$ & \\
\hline Identification and transfer flow checkist & Y & & $\sqrt{ }$ \\
\hline Linen and clothing & $\mathrm{Y}$ & & $\sqrt{ }$ \\
\hline Job description & $\mathrm{N}$ & Consultant and Matron & $\sqrt{ }$ \\
\hline Patient Selection Criteria & Y & & $\sqrt{ }$ \\
\hline Protocols and Guidelines & $\mathrm{N}$ & Matron & $\sqrt{ }$ \\
\hline
\end{tabular}




\section{Discussion}

Surgery is one of the most complex health interventions to deliver. More than 100 million people in the world receive surgical treatment every year for various reasons. Problems associated with surgical and anaesthetic safety in developed countries account for half of the avoidable adverse events that result in morbidity and mortality (1).

We were fairly satisfied with the audit done on the 7th of July. Most of the important details of the checklist were fulfilled but there were few issues which needed immediate active intervention which is discussed in the subheadings below.

\section{Infrastructure}

The UMMC Trauma Centre OT mini complex is situated $100 \mathrm{~m}$ from the main operating theatre complex of the UMMC main building (Figure 1). The infrastructure has been unused since 2003. There were attempts to run it previously, but it did not materialize because of theatre design flaws, which were not anticipated. The piping system and ceiling height were the main culprits of its non functioning status. Hence, the OT was renovated several times. All renovation were completed by March 2007. Human resource was another limiting factor due to the busy day to day running of the main OT. It was almost impossible to run another facility which was physically apart from the centre of command.

The trauma OT is situated next to the resuscitation zone and opposite the CT scan room on the trauma centre ground floor (Figure 2). It consists of two bedded reception area, two bedded recovery area, two changing room facilities and two functional operating theatres with its sub sections.

It was designed to facilitate urgent emergency surgeries; ideal for efficiency in ensuring optimal management for the patient's sake. Previously, emergency surgical patients had to travel a distance (with inclining slopes!) from the trauma centre to the main OT complex. This has resulted numerous unwanted events like cardiac arrest during transport. According to Szem et al, intra-hospital transfer for inpatients carry a significant morbidity and mortality risk. The morbidity and mortality risk increases in relation to the distance travelling by critically ill patients the further the critically ill patient travels (7).

\section{Medical gas system}

We had discussions with various divisions of UMMC engineers to sort out the problems that we came across. For example, the selected wall and attached facility gas outlets in both the main OT complex and the mini UMMC trauma centre OT were faulty. This can
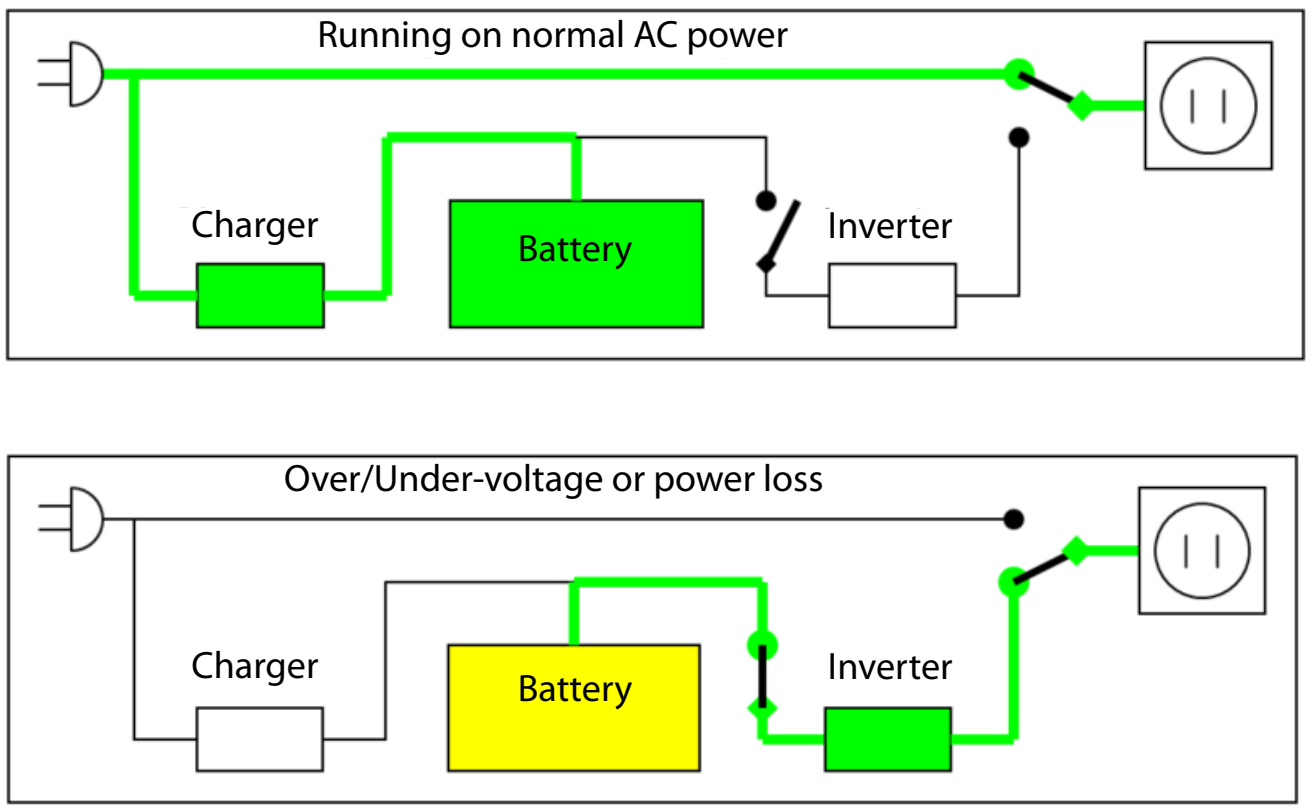

Figure 3: Simple, easy-to-understand diagram of how a Standby UPS works. 
be a cardinal sin as malfunctioning of the medical gas systems especially oxygen can endanger patients. We were unable to secure connections (failed "tug test") to both the oxygen and nitrous oxide gas outlets. One of the oxygen outlets was faulty as no oxygen flow was detected.

After a thorough inspection by the gas engineers, the problem was caused by the faulty hose outlet because it was unused for several years. Hypothetical cross piping that would cause mixture of nitrous oxide and oxygen supply should be detected by the gas analyzer in the General Anaesthetic machine (4).

Another problem that was detected was the scavenging suction system that was not functioning when checked. This is an important component as its malfunction can cause gas pollution, which in turn can create a hazardous environment to the servicing doctors and nurses. It was later discovered that the central line suction pump was faulty and immediately rectified.

\section{Electrical safety and system}

We were unable to objectively ensure electrical safety for both healthcare workers and patients according to international practice $(6,12)$. However, we were reassured by the UMMC electrical engineering team that all circuits were grounded and the hazard of microshock was minimal. We were briefed regarding the Trauma Centre's electrical safety backup (i.e. backup generator, UPS) in case of power failure. At all times in case of power failure from the main supplier, Tenaga Nasional Berhad, the trauma OT should always have adequate electrical supply by either the backup generator or the UPS system. (Figure 3)

On the 8 July, 2008, we experienced an "unintentional" blackout. It was here that we managed to identify the core electrical supply of the mini OT in the UMMC trauma centre. It was revealed later that the renovation work behind the trauma centre accidentally caused a main cable cut which was quickly repaired.

The OT lights were intermittently malfunctioning caused by the main supply wire. It was also noticed that few light bulbs were faulty. Emergency lights were obviously absent in certain parts of the complex. The UMMC Electrical division was notified and the necessary adjustments were performed immediately.

\section{Environmental factors}

The temperature, humidity and ventilation systems were inspected and found to be satisfactory. The controls and indicator were working well. However,

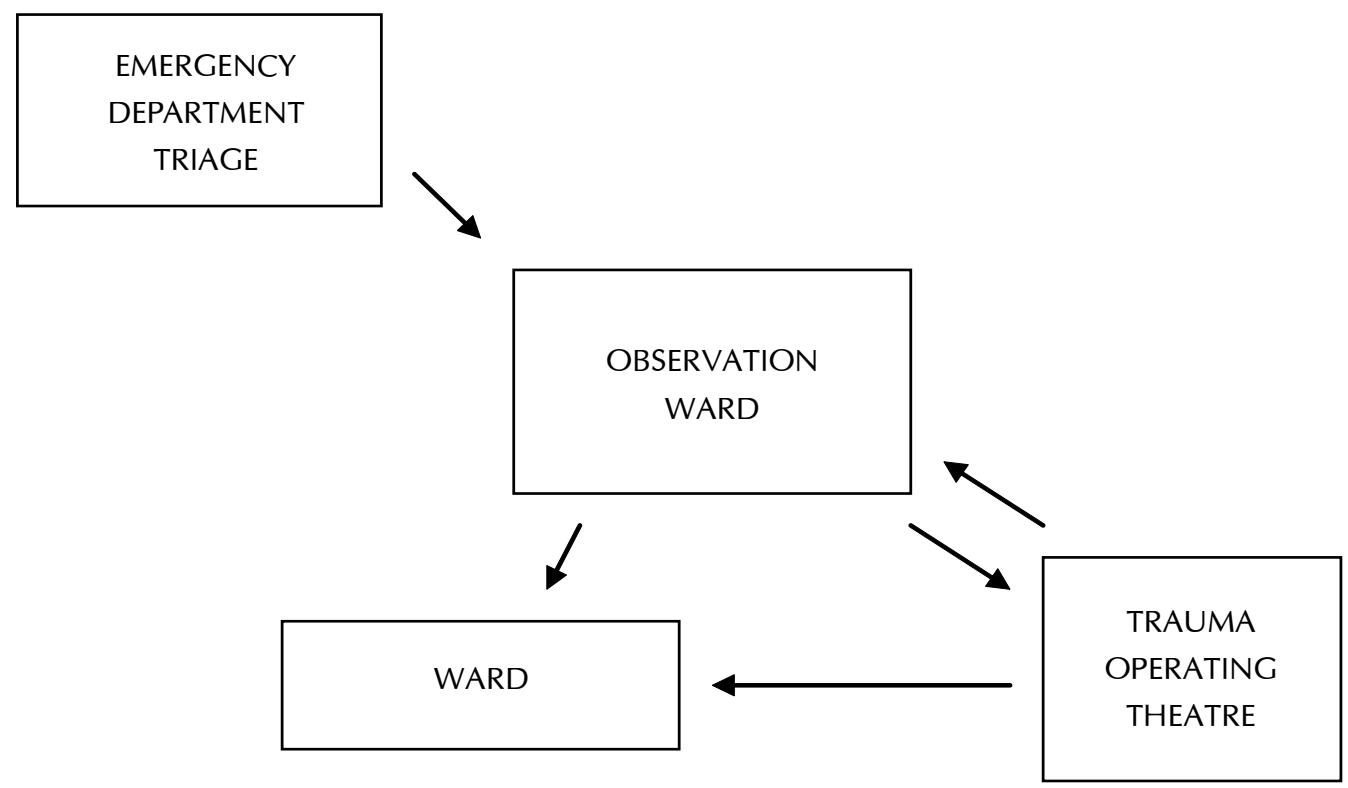

Figure 4: Patient flow from triage to Trauma OT (not to scale) 
due to power failure of the Trauma Centre on 8 July, 2008, because of ongoing construction works in the UMMC compound, the air conditioning system was not functioning. This caused high humidity and moderate temperature rise that caused both theatres to be wet and hazardous. The first case planned on the 9th of July nearly did not materialize. With the help from the engineering department, the failure was rectified.

Fire extinguishers were in good condition and placed at critical areas. Emergency exits were also easily identified and accessible.

\section{Equipment}

Both theatres were equipped with two Datex Ohmeda Aestiva 5 anaesthetic machines. They were brand new and we checked the functional status thoroughly by following the standard operating manual provided by the manufacturer. The general manager of the company that supplied the machines was also present. He counter checked and confirmed that the machines were safe to be used on patients.

Other monitoring devices were also inspected and certified fit to be used. All the monitoring devices were in accordance with the minimal monitoring standards as prescribed by ANZCA and Ministry of Health, Malaysia $(3,5)$.

Besides that, the intubation trolley, resuscitation trolley and the difficult airway trolley were strictly audited and checked to ensure that every single equipment was available and in good working condition.

\section{Patient-related aspects checklist}

The second part of the checklist was patient-related where the issues were on the administrative in nature. Effective communication between surgeons, anaesthetists and OT staff is vital for optimal patient care (11). The booking system and patient flow were thoroughly discussed between the Anaesthesiology Consultant with the operating theatre staff. Accurate documentation was necessary and it was to be complimented by smooth patient flow (Figure 4 ).

As agreed in the earlier meetings of the OT committee, when the OT is found to be satisfactory, it would undergo a two month trial. Patients who were to be operated in this theatre would adhere to few selection guidelines (Table 1). It was hoped that all minor details would be sorted out before the OT could accept "TRUE" trauma surgeries.

Table 1: Patient Selection for Trauma OT

\begin{tabular}{|c|c|}
\hline Criteria & \\
\hline $\begin{array}{l}\text { American } \\
\text { Society of } \\
\text { Anaesthesiologist } \\
\text { (ASA) Class }\end{array}$ & I and II \\
\hline \multirow[t]{3}{*}{ Patient selection } & Adult 18 and above \\
\hline & Children $2-5$ : needs discussion \\
\hline & Children<2: not suitable \\
\hline Consent & Next of kin not allowed \\
\hline Duration & Maximum 2 hours \\
\hline \multirow[t]{11}{*}{ Type of surgery } & $\begin{array}{l}\text { Haemodynamically stable patients with } \\
\text { established diagnosis }\end{array}$ \\
\hline & Example of surgeries: \\
\hline & Surgery: \\
\hline & Appendicectomy \\
\hline & Wound debridement for leg ulcers \\
\hline & Toilet and Suturing for cuts \\
\hline & ICP monitor insertion \\
\hline & Burr Hole \\
\hline & Orthopaedics: \\
\hline & Open fracture wound debridement \\
\hline & Diabetic foot ulcer debridement \\
\hline \multirow[t]{4}{*}{$\begin{array}{l}\text { Type of } \\
\text { anaesthesia }\end{array}$} & $\begin{array}{l}\text { General Anaesthesia without invasive } \\
\text { monitoring }\end{array}$ \\
\hline & Regional Anaesthesia \\
\hline & Local Anaesthesia \\
\hline & $\begin{array}{l}\text { All cases posted must be approved } \\
\text { by the Consultant Anaesthesiologist } \\
\text { and Consultant of the Emergency } \\
\text { Department }\end{array}$ \\
\hline
\end{tabular}

\section{Implementation}

On the 9th of July, 2008, there were two cases booked by the general surgery team. Only one case fulfilled the strict criteria (Table 1). The case was informed to the consultant anaesthetist in charge and she gave the green light. However, it was discovered that the theatres were all wet as a result of the impaired air conditioning. The temperature in the OT was $28^{\circ} \mathrm{C}$ and humidity at $90 \%$ because of the power failure in the trauma centre complex the previous day. The repair work was still in progress on the 9th of July, 2008. The UMMC engineers rectified the problem by 10.30 a.m. and we were satisfied with the theatre's condition at 11.45 a.m. 
A 39 year old Cambodian lady ASA 1 was planned for appendicectomy after the surgeons confirmed her clinical and investigative findings. She was admitted at 10.15 p.m. the previous night and placed in the observation ward. She was assessed by the anaesthesia trainee early in the following morning. The patient was anaesthetized at 12.10 p.m. The surgery was done within the one hour window and safely extubated. It was uneventful.

She was haemodynamically stable in the recovery area and did not require any further analgesics during her 30-minute observation there. She was later brought to the surgical ward at 2.30 p.m.

An immediate "post mortem" was done by all the staff in charge to trouble shoot and review all problems that impaired patient flow throughout the surgery. It was recorded down on a designated logbook for audit and future reference.

\section{Conclusion}

A patient's safety remains as the anaesthesiologists' main priority as perioperative physician. The anaesthesiologist takes full responsibility of the patient as soon as he or she steps into an OT $(2,5)$. This would concur to the Joint Commision International (JCl) accreditation philosophy in setting standards for hospitals focused on one goal: raising the safety and quality of care to the highest possible level (13).

Managing an OT complex may appear simple but there are many aspects to be looked into prior to starting any case. The first few chapters in any standard Anaesthesiology textbooks emphasise these issues in detail. Perfection is mandatory and morbidities and mortalities should be prevented $(8,9)$.

Efficient teamwork is vital to success in any interdisciplinary initiatives. In operating theatres, the cooperation and multilateral understanding between the doctors, nurses, supporting staff and ground staff ensures smooth operational OT flow (10). Preventing unnecessary delay in patient care will contribute to better outcome as well as reducing economic costs. Hopefully, the opening of UMMC trauma centre OT complex will pave way for more efficient use of time, optimal patient safety and minimize unnecessary resource allocation for the local setting.

\section{References}

1. WHO Patient Safety. World Health Organisation. Available from http://www.who.int/patientsafety/ en/index.html. Accessed June 2009.

2. Anaesthesia and Intensive Care Service, Operational Policy. MOH/P/PAK/142.07 (BP) February 2008.

3. Academy Of Medicine Malaysia, Chapter of Anaesthesiologists, April 2003. Recommendations for Safety Standards and Monitoring During Anaesthesia and Recovery.

4. Australia and New Zealand College of Anaesthesiologists 2003, P31. Recommendations on Checking the Anaesthetic Delivery System.

5. Australia and New Zealand College of Anaesthesiologists. T12000. Recommendations on Minimum Facilities for Safe Anaesthesia Practice in Operating Suites.

6. Malaysian Standards approved on 21/02/2007 by the Ministry of science, technology and innovation in accordance with the standards of Malaysian Act(ACT 549) ISC D: Building and Civil Engineering, ISC E: Electrotechnical, ISC R: Medical Devices.

7. Szem JW, Hydo LJ, Fischer E, Kapur S, Klemperer J, Barie PS. High-risk intrahospital transport of critically ill patients: safety and outcome of the necessary "road trip". Crit Care Med 1995; 23: 16601666.

8. Morgan GE, Mikhaeil MS, Murray MJ, Larson CP. Clinical anaesthesiology. 3rd Ed. NY: McGraw Hill, 2002.

9. Bland $H$. The supply of anaesthetic and other medical gases. In: Davey AJ, Diba A. ed. Ward's Anaesthetic Equipment. 5th Ed. Philadelphia: Elsevier; 2005: 23-47.

10. Reason J. Safety in the operating theatre-Part 2: Human error and organisational failure Qual Saf Health Care 2005; 14: 56-60.

11. Schaefer HG, Helmreich RL, Scheidegger D. Safety in the operating theatre-part 1: interpersonal relationships and team performance. Current Anaesthesia Critical Care. 1995; 6: 48-53. 
12. Boumphrey $S$, Langton. JA Electrical safety in the operating theatre. $\mathrm{Br} J$ of Anaesthesi CEPD Reviews. Feb 2003 1: 1.10-14(5).

13. Joint Commission International $(\mathrm{JCl})$, WHO Collaborating Centre. Available from http://www. jointcommissioninternational.org/about-jci/. Accessed June 2009. 


\title{
CARBIMAZOLE-INDUCED APLASTIC ANAEMIA-A CASE REPORT
}

\author{
Vijay AP, Lim SS, Tan ATB, Rokiah P and Chan SP \\ Department of Medicine (Endocrinology), Faculty of Medicine, Universiti Malaya, Kuala Lumpur
}

\begin{abstract}
Antithyroid drugs have been used for more than 50 years for the management of hyperthyroidism. Most patients tolerate treatment well, but some may develop rare life threatening side effects such as agranulocytosis and aplastic anaemia. Clinical experience with the latter condition is extremely limited. We report on a case of carbimazole-induced aplastic anaemia caused by hypocellular bone marrow and associated plasmacytosis in a thyrotoxic patient chronically treated with carbimazole. This resolved after substitution with propylthiouracil. The clinical course was complicated by neutropaenic septicaemia and atrial fibrillation. (JUMMEC 2009; 12 (2): 92-95)
\end{abstract}

KEYWORDS: thyrotoxicosis, carbimazole, aplastic anaemia, plasmacytosis

\section{Introduction}

A 37-year old single Malay male who smoked 20 cigarettes a day, presented to us on the 9 February, 2007, with a two week history of fever, chills, sore throat, lethargy, decreased exercise tolerance, dyspnoea, vomiting, diarrhoea, loss of appetite and loss of six kilograms in weight.

He had been diagnosed with Graves' disease and thyrotoxicosis in 1996 and treated with carbimazole and propranolol by his general practitioner, but he had not been compliant and stopped treatment in December 2006. He was initially presented to another tertiary centre on 19 January, 2007, and was noted to be thyrotoxic and in atrial fibrillation. He was commenced on carbimazole $20 \mathrm{mg}$ BD and propranolol $20 \mathrm{mg}$ TDS and discharged. Full blood counts $(\mathrm{FBC})$ at this time showed haemoglobin $(\mathrm{Hb})$ $14.9 \mathrm{~g} / \mathrm{dL}$, leucocytes (WC) $6.7 \times 10^{9} / \mathrm{L}$ and platelets (PIt) $201 \times 10^{9} / \mathrm{L}$. He was discharged the next day and became unwell a week later.

\section{Methodology}

On admission, he was alert and comfortable, but dehydrated, tremulous, and febrile at $38.3^{\circ} \mathrm{C}$. His throat was erythematous with a small right cervical lymph node. A small diffuse goiter was present and lid lag was noted, but there were no other eye signs. He was in atrial fibrillation with an apical rate of $146 / \mathrm{min}$, but reverted spontaneously to sinus rhythm of $90 / \mathrm{min}$. There was no evidence of cardiac decompensation. TSH $<0.01 \mathrm{mlu} / \mathrm{L}$, free T4 $95.3 \mathrm{pmol} / \mathrm{L}$, free T3 23.2 pmol/L. Full blood count showed Hb $16.3 \mathrm{~g} / \mathrm{dL}$, WC
$1.6 \times 10^{9} / \mathrm{L}$, ANC $0.8 \times 10^{9} / \mathrm{L}$, Plt $33 \times 10^{9} / \mathrm{L}$. Chest radiograph was normal. Carbimazole was discontinued, and he was commenced on propylthiouracil $200 \mathrm{mg}$ QID, Lugol's iodine 10 drops TDS, propranolol $20 \mathrm{mg}$ TDS and intravenous hydration. Antibiotic therapy with piperacillin/tazobactam $4.5 \mathrm{~g}$ TDS was started.

The patient's general condition improved and he was subsequently afebrile. Blood, urine and sputum cultures were negative. Platelets fell to $7 \times 10^{9} / \mathrm{L}$ on 12 February, 2007, and he was transfused with four units of platelets although there was no bleeding tendency.

Bone marrow aspirate and trephine (BMAT) biopsy of the right posterior iliac crest on 13 February, 2007, revealed a few marrow fragments which were very hypocellular with no clumps within the stromal tissue. Lymphocytes and plasma cells were seen (Figure 1). Erythropoesis and granulopoesis were markedly depressed with dysplastic granulopoetic maturation. Megakaryocytes were virtually absent. No clusters of abnormal cells were seen and there was no increase of reticulin fibres. Granulocyte colony stimulating factor (GCSF) was not given at this stage after discussion with our haematology colleagues.

\section{Correspondance:}

Vijay Ananda A/L Paramasvaran

Department of Medicine

Faculty of Medicine, Universiti Malaya

50630 Kuala Lumpur

Email:vananda@gmail.com 


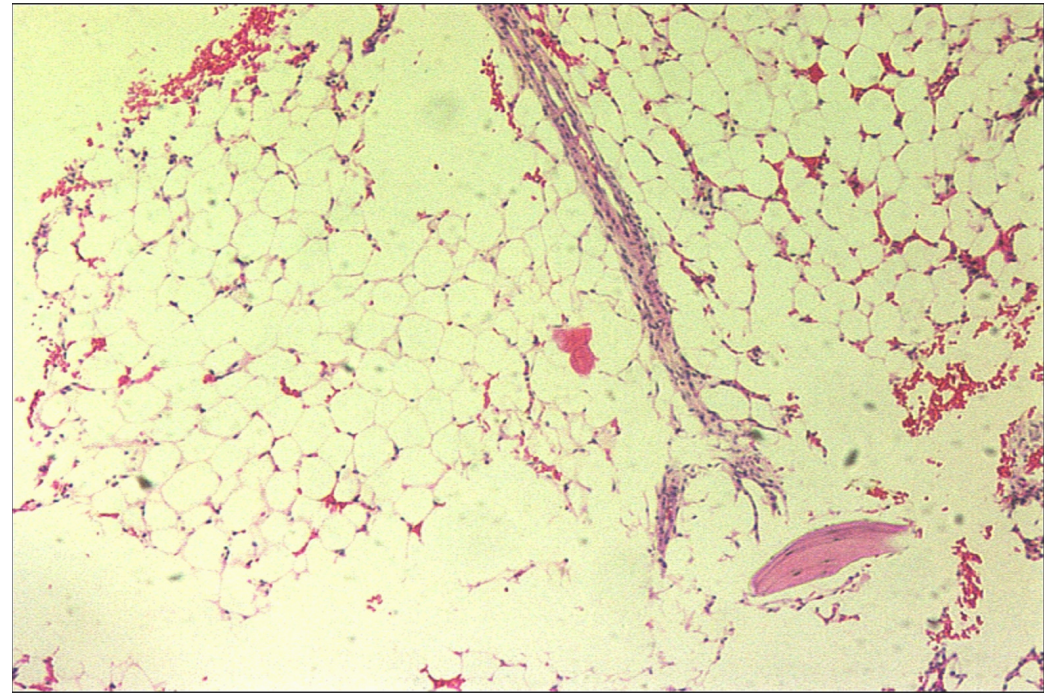

Figure 1: Hypocellular marrow (Trephine biopsy)

On 14 February, 2007, Lugol's lodine was stopped. His temperature spiked to $38.2{ }^{\circ} \mathrm{C}$ two days later, and he became hypotensive. Septic work up was repeated and his antibiotics was changed to imipenem 500 mg TDS. Propranolol was discontinued. He recovered and remained well subsequently, but had to be recommenced on propranolol on 21 February, 2007, after he was noted to be having paroxysms of atrial fibrillation. Repeat blood cultures were negative. He was discharged the same day with ciprofloxacin 500mg TDS and amoxicillin and clavulanic acid $625 \mathrm{mg}$ TDS. $\mathrm{Hb}$ was $11.8 \mathrm{~g} / \mathrm{dL}$, WC $1.6 \times 10^{9} / \mathrm{L}$, ANC $0.06 \times 10^{9} / \mathrm{L}$, PIt 20 $\mathrm{x} 10^{9} 109 / \mathrm{L}$.

His blood counts normalized on 12 March 200730 days after initial presentation (Figure 2 and 3). Transthoracic echocardiogram was normal with good left ventricular ejection fraction of $70 \%$. He was later anticoagulated with warfarin after his platelet count had recovered. His antithyroid drugs were gradually tapered and he subsequently received radioactive lodine 131 therapy at a dose of $10 \mathrm{mCi}$ on 5 November, 2007, which rendered him euthyroid.

\section{Discussion}

The infrequent and often serious idiosyncratic drug reaction of agranulocytosis (ANC $<0.5 \times 10^{9} / \mathrm{L}$ ) is a well recognized side effect $(0.2-0.5 \%)$ of treatment with the antithyroid drugs (ATD's) carbimazole, methimazole and propylthiouracil (1). However, aplastic anemia is rare with only 34 cases reported and about 17 adequately documented, not including this case. It is thought to be a humoral autoimmune response which results in transient bone marrow aplasia. Two cases have been reported with Propylthiouracil. There have been two fatalities reported from intracerebral haemorrhage (2-6).

Patients usually present with symptoms of agranulocytosis between one and four months after commencing ATD's. Unusually, in this case there is history of long term carbimazole use although this has been described in other reports (7). Laboratory findings are of aplasia of the bone marrow and pancytopaenia in the peripheral blood. Recovery of all cell lines occurred two to five weeks after discontinuing the offending drug. The prognosis with carbimazoleinduced aplastic anaemia is better than with other forms of drug induced aplastic anaemia. The prognosis is linked to the degree of hypoplasia in the marrow.(2, 4).

The role of G-CSF in aiding granulocyte recovery in ATD-induced aplastic anaemia is not clear as it has been used in only three cases. Reports suggest that it may be more effective in moderate than in severe cases. No other predictors of response are known (4, 8). Due to a delay in BMAT findings, G-CSF was not given on initial presentation and was felt unnecessary later as the patient remained well clinically. Propylthiouracil was used guardedly as the patient was still markedly thyrotoxic and at risk of cardiac arrhythmias. Lithium and cholestyramine have been 

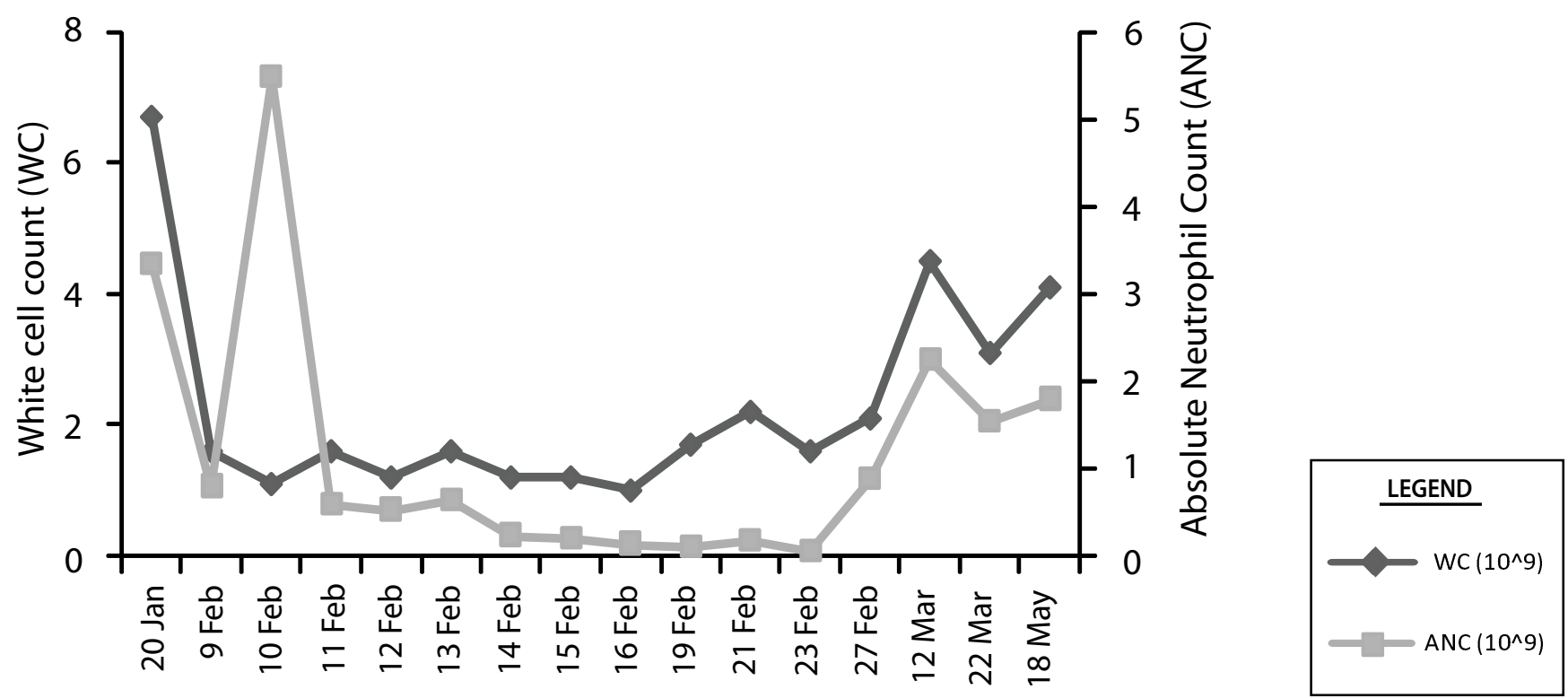

Figure 2: Leucocyte and absolute neutrophil count trend
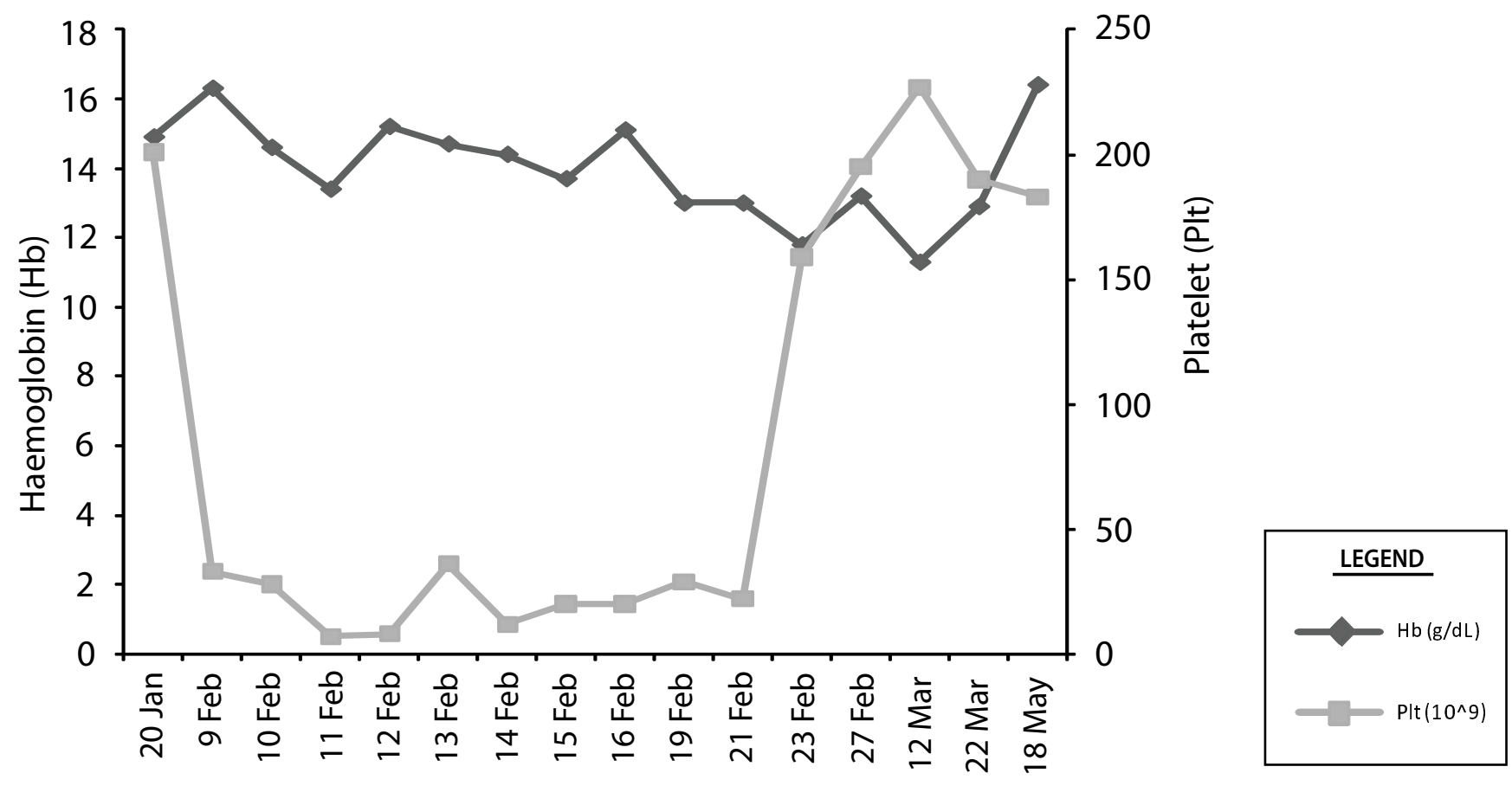

Figure 3: Haemoglobin and platelet trend

used to replace conventional ATD's to prevent recurrent thyrotoxicosis. Of interest, lithium may have an effect of promoting granulopoeisis $(4,8)$. Corticosteroids have been used successfully, but were withheld here due to the possibility of serious underlying infection (9).
To our knowledge, there are only two reports of plasmacytosis associated with carbimazole-induced aplastic anaemia. Both patients recovered after drug withdrawal with complete marrow recovery. The presence of plasma cells lends weight to an 
immunogenic aetiology of this rare complication of ATD use $(10,11)$.

Routine $\mathrm{FBC}$ is not advocated in patients commencing on ATD's. It is important to provide verbal or written instructions to patients to quickly report symptoms of agranulocytosis, which predominate and can present rapidly in an outpatient setting.

\section{References}

1. Cooper DS. Treatment of thyrotoxicosis, and Wartofsky L. Thyroid storm. In: Braverman LE \& Utiger RD. eds. Werner and Ingbar's the thyroid: A fundamental and clinical text. 8th edition. Philadelphia: JB Lippincott Williams and Wilkins; 2000: 679-684, 691-715.

2. Biswas N, You-hern A, Goldman JM, Schwartz JM. Case report: Aplastic anaemia associated with antithyroid drugs. Am J Med Sci 1991; 301: 190-194.

3. Escobar-Morreale HF, Bravo P, Garcia-Robles R, Garcia-Larana J, de la Calle H, Sancho JM. Methimazole-induced severe aplastic anaemia: unsuccessful treatment with recombinant human granulocyte-monocyte colony stimulating factor. Thyroid 1997; 7: 67-70.

4. Wilcox G, Wong R, Elliot PJ, Topliss DJ, Stockigt JR. Case report: Recovery from carbimazole-induced aplastic anaemia. Int J of Endocrinol \& Metab 2003; 1: 41-43.

5. Moreb J, Shemesh O, Shilo S, Manor C, Hershko C. Transient methimazole-induced bone marrow aplasia: In vitro evidence for a humoral mechanism of bone marrow suppression. Acta Haematologica 1983; 69(2): 127-131.
6. Thomas D, Moisidis A, Tsiakalos A, Alexandrai K, Syriou V, Kaltsas G. Antithyroid drug induced aplastic anaemia. Thyroid 2008; 18(10): 1043-48.

7. Mezquita P, Luna V, Munoz-Torres M, Torres-Vela E, Lopez-Rodriguez F, Calleja JL, et al. Methimazoleinduced aplastic anaemia in third exposure: successful treatment with human G-CSF. Thyroid 1998; 8: 791-794.

8. Gallicchio VS. Lithium stimulation of in vitro granulopoesis: evidence for mediation via sodium transport pathways. Br J Haematol 1986: 62: 455466.

9. Jakucs J, Pocsay G. Successful treatment of methimazole-induced severe aplastic anaemia with recombinant human G-CSF and high dose steroids. J Endocrinol Invest 2006 Jan; 29(1): 74-77.

10. Brier DV, Rendo P, Gonzalez J, Shilton G, Stivel M, Goldztein S. Massive plasmacytosis due to methimazole-induced bone marrow toxicity. Am J Haematol 2001 Aug; 67(4): 259-261.

11. Yamamoto A, Katayama Y, Tomiyama K, Hosoai $\mathrm{H}$, Hirata F, Kimura F, et al. Methimazole-induced aplastic anaemia caused by hypocellular bone marrow with plasmacytosis. Thyroid 2004 Mar; 14(3): 231-235. 


\section{List of Reviewers for Volume 12, Issues 1 \& 2, 2009}

\section{Associate Professor Quek Kia Fatt}

School of Medicine \& Health Sciences, Monash

University Sunway Campus, Petaling Jaya, Selangor

\section{Dr Ben Selladurai}

Sime Darby Medical Centre, Subang Jaya, Selangor

\section{Dr Claire Choo Wan Yuen}

Department of Social \& Preventive Medicine, Faculty of Medicine, University of Malaya, Kuala Lumpur

\section{Dr Jeyamalar Rajadurai}

Sime Darby Medical Centre, Subang Jaya

\section{Dr Lim Soo Kun}

Department of Social \& Preventive Medicine, Faculty of Medicine, Universiti Malaya, Kuala Lumpur

\section{Dr Moy Foong Ming}

Department of Social \& Preventive Medicine, Faculty of Medicine, Universiti Malaya, Kuala Lumpur

\section{Dr Razali Omar}

National Heart Institute (IJN), Kuala Lumpur

\section{Dr Sanjay Rampal}

Department of Social \& Preventive Medicine, Faculty of Medicine, Universiti Malaya, Kuala Lumpur

\section{Professor Atiya Abdul Sallam}

Consultant, Faculty of Medicine, Universiti Malaya, Kuala Lumpur

\section{Professor Cheong Soon Keng}

Faculty of Medicine and Health Sciences, University Tunku Abdul Rahman (UTAR), Sg Long, Selangor

\section{Professor Jaafar Md Zain}

Department of Anaesthesia, Faculty of Medicine, University of Malaya, Kuala Lumpur

\section{Professor Jamiyah Hassan}

Department of Obstetrics \& Gynaecology, Faculty of Medicine, Universiti Malaya, Kuala Lumpur

\section{Professor Kulenthran Arumugam}

Consultant, Medical Research Development Unit (MERDU), Faculty of Medicine, Universiti Malaya, Kuala Lumpur

\section{Professor Mohd Yasim Mohad Yusof}

Department of Medical Microbiology, Faculty of Medicine, Universiti Malaya, Kuala Lumpur

\section{Professor Nik Abdullah Nik Mohammad}

Deputy Dean (Postgraduate), Faculty of Medicine, University Science Malaysia, Kubang Kerian, Kelantan

\section{Professor Ramani Vijayan Sannasi}

Department of Anaesthesiology, Faculty of Medicine, Universiti Malaya, Kuala Lumpur

\section{Professor Mohamed Razif Mohamed Ali}

Sports Medicine Unit, Faculty of Medicine, Universiti Malaya, Kuala Lumpur

\section{Professor Rokiah Pendek}

Department of Medicine, Faculty of Medicine, Universiti Malaya, Kuala Lumpur

\section{Professor S. Fadilah Abdul Wahid}

Department of Medicine, Faculty of Medicine, National University of Malaysia, Kuala Lumpur

\section{Professor Siti Zawiah Omar}

Department of Obstetrics \& Gynaecology, Faculty of Medicine, Universiti Malaya, Kuala Lumpur

\section{Professor Vickneswaran CM}

Consultant Neurosurgeon, Department of Surgery, Faculty of Medicine, Universiti Malaya, Kuala Lumpur 


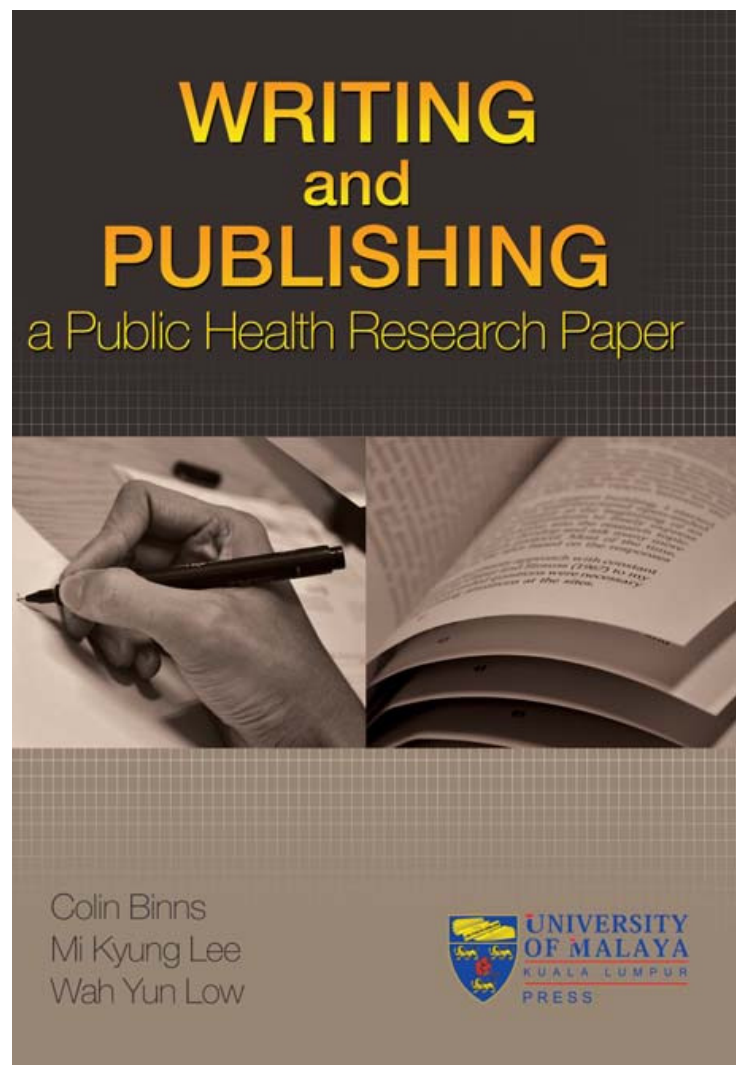

Title: Writing and Publishing A Public Health Research Paper

Authors: Colin Binns, Mi Kyung Lee \& Wah Yun Low

ISBN: 978-983-100-483-8

Price: US\$30

Publisher: University of Malaya Press

Website: http://umpress.um.edu.my

HERE is a short book on writing papers that is based on experience. The authors are experienced researchers who have published many papers on public health in Asia. The book is based on the practical experiences of the authors in running workshops for the Asia Pacific Academic Consortium for Public Health and their own universities. The workshop participants came from a variety of health professions in different countries and their needs and the questions they asked are reflected in this book. Often the text is in point form and contains checklists for authors. The English style is basic and is suited for those who have English as a second language.

THE book gives practical advice on all of the major types of papers in public health and the health sciences. A template to assist in writing and an article for the Asia Pacific Journal of Public Health or a similar journal is included. Following this example will ensure that a beginning author will meet all of the editorial style requirements for publication. There are examples of tables and graphs and letters of submission to the editor. References to further sources of information on writing papers are included.

HERE is a concise, yet comprehensive guide to publication in public health. While aimed at beginning academics and health professionals, the book will also be a useful resource to improve the publication rates of those further along the career path. Follow the templates and guidelines and you will be heading to success in publication. This book is a must for all who have a good news story tell about the achievements of public health.

More information about this book, and how to order it can be obtained by contacting

Ms Azah Afzan (Marketing Officer):

Address: Department of Publications University of Malaya,

Pantai Valley, 50603 Kuala Lumpur,

Malaysia

Telephone: 603-7957 4361

Fax: 603-7957 4473

E-mail: azahafzan@um.edu.my 